\title{
Toxic oligopeptides in the cyanobacterium Planktothrix agardhii-dominated blooms and their effects on duckweed (Lemnaceae) development
}

\author{
Barbara Pawlik-Skowrońska ${ }^{1, *}$, Magdalena Toporowska ${ }^{1}$ and Hanna Mazur-Marzec ${ }^{2}$ \\ ${ }^{1}$ Department of Hydrobiology and Protection of Ecosystems, University of Life Sciences in Lublin, Dobrzańskiego 37, 20-262 Lublin, \\ Poland \\ ${ }^{2}$ Department of Marine Biotechnology, University of Gdańsk, al. Piłsudskiego 46, 81-378 Gdynia, Poland
}

\begin{abstract}
Cyanobacterial toxins are a global threat to aquatic organisms; however, they represent only one group of bioactive cyanobacterial metabolites. Very little is known about the effects of other cyanobacterial products (e.g., non-ribosomal oligopeptides) on freshwater macrophytes. Our experimental study revealed that the development of young duckweed Spirodela polyrhiza was inhibited by two aquatic extracts of cyanobacterial bloom samples predominated by Planktothrix agardhii and pure microcystin-LR (MC-LR). The extracts differed considerably in the content of MCs and other oligopeptides; they contained three or four MC variants and several other oligopeptides such as anabaenopeptins, aeruginosins, and planktocyclin. Their toxic effects on young plants (first frond area, root number, fresh biomass, and chlorophyll $a$ content) were different. The more phytotoxic extract obtained from a higher cyanobacterial biomass contained a lower total $\mathrm{MC}$ concentration and different anabaenopeptin variants (e.g., anabaenopeptin H, G, HU892, and E/F) as well as planktocyclin, which were not present in another extract with a higher MC concentration. The obtained results suggested that $P$. agardhii oligopeptides other than MCs are harmful to young duckweeds and may exert even stronger toxic effects than MC-LR. The production of various variants of MCs together with other oligopeptides, and their toxicity to aquatic plants varied over seasons depending on the taxonomic composition of the cyanobacterial bloom. Germinated turions of $S$. polyrhiza can be used as a sensitive bioindicator of the cyanobacterial threat in aquatic ecosystems.
\end{abstract}

Keywords: Aeruginosins / anabaenopeptins / microcystins / non-ribosomal peptides / macrophyte

Résumé - Oligopeptides toxiques dans les fleurs d'eau dominées par la cyanobactérie Planktothrix agardhii et leurs effets sur le développement des lentilles d'eau (Lemnaceae). Les toxines cyanobactériennes constituent une menace mondiale pour les organismes aquatiques ; cependant, elles ne représentent qu'un seul groupe de métabolites cyanobactériens bioactifs. On sait très peu de choses sur les effets d'autres produits cyanobactériens (p. ex. oligopeptides non ribosomiques) sur les macrophytes d'eau douce. Notre étude expérimentale a révélé que le développement des jeunes lentilles d'eau Spirodela polyrhiza a été inhibé par deux extraits aquatiques d'échantillons de fleurs d'eau à cyanobactéries, dominées par Planktothrix agardhii et de la microcystine-LR pure (MC-LR). Les extraits différaient considérablement dans le contenu en $\mathrm{MC}$ et d'autres oligopeptides ; ils contenaient trois ou quatre variantes MC et plusieurs autres oligopeptides tels que les anabaénopeptines, les aéroginosines et la planctocycline. Leurs effets toxiques sur les jeunes plantes (première pousse, nombre de racines, biomasse fraîche et teneur en chlorophylle $a$ ) étaient différents. L'extrait phytotoxique obtenu à partir d'une biomasse cyanobactérienne plus élevée contenait une concentration totale de MC plus faible et différentes variantes d'anabaénopeptine (p. ex. anabaénopeptine H, G, HU892 et E/F) ainsi que de la planctocycline, qui n'étaient pas présentes dans un autre extrait ayant une concentration de $\mathrm{MC}$ plus élevée. Les résultats obtenus suggèrent que les oligopeptides de $P$. agardhii autres que les MC sont nocifs pour les jeunes lentilles d'eau et peuvent exercer

\footnotetext{
*Corresponding author: barbara.pawlik@up.lublin.pl
} 
des effets toxiques encore plus importants que les MC-LR. La production de diverses variantes de MCs avec d'autres oligopeptides et leur toxicité pour les plantes aquatiques ont varié au fil des saisons en fonction de la composition taxonomique du bloom cyanobactérien. Les turions germés de S. polyrhiza peuvent être utilisés comme bioindicateur sensible de la menace cyanobactérienne dans les écosystèmes aquatiques.

\section{Introduction}

Harmful cyanobacterial blooms are a global threat to aquatic ecosystems (Metcalf and Codd, 2012; Pearl, 2014). In eutrophic freshwaters of the temperate climate zone, heavy water blooms formed by several cyanobacterial genera such as Microcystis, Dolichospermum (syn. Anabaena), and Planktothrix frequently develop (O'Neil et al., 2012). These cyanobacteria produce a set of different variants of hepatotoxic microcystins (MCs) as well as other oligopeptides (Welker and von Döhren, 2006) having diverse biological activities (e.g., inhibition of proteases or other metabolically important enzymes; Chlipala et al., 2011). In European lakes and dam reservoirs with nutrient-rich waters, blooms of MC-producing and some non-producing Planktothrix agardhii have been frequently reported (Yepremian et al., 2007; Briand et al., 2008; Pawlik-Skowrońska et al., 2008; Rohrlack et al., 2009). It is impossible to predict the development of particular subpopulations - toxic and/or non-toxic - within cyanobacteria because of the differences at the level of expression of the genes involved in the MC biosynthesis and in the effects of variable environmental factors (Briand et al., 2008). As reported recently by Kurmayer et al. (2016), among the $P$. agardhii populations, both high MC-producing and low MCproducing strains occur, and the genotypic variation concerns both MCs and other bioactive oligopeptide synthesis genes. The accumulation and toxic effects caused by MCs in animal organisms were noted (Pawlik-Skowrońska et al., 2013; Toporowska and Pawlik-Skowrońska, 2014; Barrios et al., 2015). Toxic effects (e.g., inhibition of photosynthesis and reduction in growth) of the individual MCs MC-LR and MCRR towards some aquatic plants were also reported (Weiss et al., 2000; Pietsch et al., 2001; Wiegand and Pflugmacher, 2005; Mitrovic et al., 2005). MCs that are inhibitors of protein phosphatases PP1 and PP2A constitute less than 20\% of the oligopeptides produced by cyanobacteria (Wiegand and Pflugmacher, 2005); however, little information is available on the toxic activity of cyanobacterial metabolites, other than MCs, towards aquatic organisms. During cyanobacterial water blooms, MCs occur mainly intracellularly; however, during and after the bloom decay, they occur in high concentrations in the surrounding water. For example in spring, in a Polish lake with $P$. agardhii bloom $11 \mu \mathrm{g} \mathrm{L}^{-1}$ of dissolved MCs was found (Pawlik-Skowrońska et al., 2008). Nasri et al. (2004) reported $712 \mu \mathrm{gL}^{-1}$ of dissolved MCs during Microcystis bloom collapse. Even up to $1800 \mu \mathrm{g} \mathrm{MCs} \mathrm{L}^{-1}$ was found after the treatment of the bloom with an algicide (Jones and Orr, 1994). Approximately 600 different oligopeptides having various biological activities have been reported in cyanobacteria (Welker and von Döhren, 2006). They can also be released from the decaying cells into the surrounding water; therefore, there is an urgent need for the complete understanding of their toxicological potential in inland waters. Thus far, apart from
MC-LR, very little is known about the effects of other cyanobacterial oligopeptides on aquatic plants. For example, in the green macroalga Cladophora fracta and aquatic macrophytes (Wolffia arrhiza and Ceratophyllum demersum), MC-LR-induced changes in the activity of stress enzymes were observed (Pflugmacher, 2004; Mitrovic et al., 2005). Toxic effects of the Microcystis extract on the growth and chlorophyll content of two species of Lemnaceae have also been reported (Romanowska-Duda et al., 2002; Saqrane et al., 2007). Microcin Sf608 isolated from Microcystis sp. inhibited the activity of several enzymes in water moss (Wiegand et al., 2002). The toxin-producing cyanobacterium P. agardhii, common in the eutrophic natural and artificial water bodies of the temperate zone, causes perennial water blooms (Halvsted et al., 2007; Arnaud et al., 2008; PawlikSkowrońska et al., 2008). MCs released from cells after bloom collapse remain in water until the following spring (Pawlik-Skowrońska et al., 2008) and can affect the development of aquatic plants. The oligopeptide profiles of cyanobacterial bloom samples may change with time and taxonomic structure. Therefore, we studied the oligopeptide profiles of two $P$. agardhii-dominated blooms sampled in different years and the effects of these metabolites on the early stage of development of Spirodela polyrhiza, a duckweed, that inhabits inland waters. The aim of this study was to highlight the possible contribution of oligopeptides, other than MCs, to the cyanobacterial toxicity towards aquatic plants.

\section{Materials and methods}

\subsection{Organisms}

S. polyrhiza turions (dormant stage of the plant), used in the bioassays, were obtained within the framework of the Interlaboratory Comparison of the Spirodela Duckweed Microbiotest (MicroBioTests Company). "Steinberg medium" prescribed by ISO for Lemna toxicity tests (ISO 20079, 2005) was used for the germination of the S. polyrhiza turions as a growth medium for the young plants. Turions were incubated in a Petri dish with the sterile medium for 3 days at $25^{\circ} \mathrm{C}$ with continuous "top" illumination (6000 lux) according to the instruction of the producer.

Two $P$. agardhii-dominated bloom samples (Pa-A and $\mathrm{Pa}-\mathrm{B})$ were collected in the surface layer of water in the shallow (max. depth: $2.9 \mathrm{~m}$ ) and hypertrophic Lake Syczyńskie (E. Poland, $51^{\circ} 17^{\prime} 12^{\prime \prime} \mathrm{N}, 23^{\circ} 14^{\prime} 16^{\prime \prime} \mathrm{E}$ ) in the summer 2008 and 2010 , respectively. The biomass of $\mathrm{Pa}-\mathrm{A}$ scum sample consisted in $97 \%$ of $P$. agardhii and in about 3\% of Aphanizomenon gracile and Dolichospermum spp., while the biomass of Pa-B bloom sample concentrated with a phytoplankton net $(25 \mu \mathrm{m})$ consisted in $95 \%$ of $P$. agardhii and in 5\% of Microcystis aeruginosa. The quantitative composition (abundance and biomass) of cyanobacteria was analysed by light microscopy (Zeiss Primo Star) in a 
1-mL phytoplankton Sedgewick-Rafter chamber. Fresh weight (FW) of cyanobacteria was obtained by measuring the biovolume of 30-50 individuals in accordance with Hillebrand et al. (1999) and multiplication of the results by the abundance of particular taxa. The chlorophyll $a$ concentration in the extracts of the cyanobacterial bloom samples was determined according to PN-ISO 10260 (2002).

\subsection{Extraction and HPLC-DAD analysis}

Dense samples of the cyanobacterial biomass $(5 \mathrm{~mL})$ were used to prepare crude extracts for the determination of MCs and toxicological bioassays. The material was briefly sonicated, and after centrifugation $(14000 \times g$ for $10 \mathrm{~min}$ at $\left.17^{\circ} \mathrm{C}\right)$, the supernatants were collected and frozen $\left(-20^{\circ} \mathrm{C}\right)$ until the day of cyanotoxin analysis and bioassays.

The HPLC-photodiode array detection system (Shimadzu) was used for the detection and preliminary identification of $\mathrm{MC}$ in the crude cyanobacterial extracts. The UV detection range was 200-300 nm. MC-LR, - RR, - YR, -LA, -LY, $-\mathrm{LW},-\mathrm{LF},-\mathrm{WR}$, and -HtyR (Alexis) were used as the standards. The extract components were separated using a Purosphere column $(125 \mathrm{~mm} \times 3 \mathrm{~mm}$, dp $5 \mu \mathrm{m}$, Merck) with the mobile phase composed of acetonitrile (Merck): water acidified with $0.05 \%$ trifluoroacetic acid (gradient: $30 \%$ $100 \%$, at a flow rate of $0.7 \mathrm{~mL} \mathrm{~min}^{-1}$.

\subsection{LC-MS/MS analysis of oligopeptides}

Two 10-mL $P$. agardhii-dominated bloom samples (Pa-A and $\mathrm{Pa}-\mathrm{B}$ ) were filtered onto the $\mathrm{GF} / \mathrm{C}$ glass-fibre filters (Whatman). The material was extracted with $2.0 \mathrm{~mL}$ of $5 \%$ acetic acid in Milli-Q water by 1-min probe sonication with an ultrasonic disrupter (HD 2070 Sonopuls, Bandeline, Berlin, Germany) followed by $15 \mathrm{~min}$ of bath sonication (Sonorex, Bandeline, Berlin, Germany). The samples were then centrifuged at $10000 \times g$ for $15 \mathrm{~min}$, and the obtained supernatants were subjected to an LC-MS/MS analysis. Agilent 1200 (Agilent Technologies, Waldboronn, Germany) coupled online to a hybrid triple quadrupole/linear ion trap mass spectrometer (QTRAP5500, Applied Biosystems, Sciex; Concorde, ON, Canada) was used for the analysis, as described in Mazur-Marzec et al. (2013).

\subsection{Toxicity bioassays}

The toxicity bioassays were performed in five replicates in cups $(\mathrm{V}=2 \mathrm{~mL})$ of multi-well plates using the Steinberg medium (the same as that for the germination of $S$. polyrhiza turions). Each 72-h-old plant was placed into experimental cups containing 332 and $3320 \mu \mathrm{g}$ of pure MC-LR per litre, or five dilutions of the two extracts $\mathrm{Pa}-\mathrm{A}$ and $\mathrm{Pa}-\mathrm{B}$, obtained from the cyanobacterial blooms sampled in two different years. Both cyanobacterial crude extracts $(\mathrm{Pa}-\mathrm{A}$ and $\mathrm{Pa}-\mathrm{B})$ used in the toxicity bioassays were diluted from 2 to 16 times. As a result, the final concentration ranges of MCs from 71 to $1136 \mu \mathrm{g} \mathrm{L}^{-1}$ in the case of the extract Pa-A and from 5.5 to $88 \mu \mathrm{g} \mathrm{L}^{-1}$ in the case of the extract $\mathrm{Pa}-\mathrm{B}$ were obtained. Two controls (in five replicates each) were also set. The plants were incubated for the following $96 \mathrm{~h}$ of the experiment at $25^{\circ} \mathrm{C}$ with continuous illumination (6000 lux).

\subsection{Analyses of growth parameters}

After the 96-h exposure, the following steps were performed:

- The growth of the first frond (surface area in $\mathrm{mm}^{2}$ ) of the exposed and control plants was determined from the photos of multi-well plates by using ImageJ and Microsoft Excel for the data treatment. The photos were taken with a digital camera at the start and at the end of the toxicity test. The inhibition of the growth of the exposed plants was evaluated considering the 96 -h plant growth in the controls as $100 \%$.

- The number of roots of each plant was counted directly.

- The total biomass (as fresh weight or FW) of each plant was measured after gentle drying with a filter paper and weighting. The FW was expressed to an accuracy of $0.0001 \mathrm{mg}$.

\subsection{Analysis of chlorophyll a}

- Each weighted plant was grinded with a glass spatula and then homogenised in $4 \mathrm{~mL}$ of $90 \%$ ethanol for $20 \mathrm{~min}$ at $20{ }^{\circ} \mathrm{C}$. The homogenate was centrifuged at $14000 \times g$ for $10 \mathrm{~min}$. The absorbance of the chlorophyll extract was measured at 665 and $750 \mathrm{~nm}$ with the SPECORD 40 spectrophotometer.

\subsection{Data analysis}

All of the data obtained in the bioassays were expressed as mean values $(n=5) \pm$ standard error of the mean (SE). Significant differences among treatments were evaluated using one-factor analysis of variance (ANOVA). Pair-wise comparison of means was done using the Tukey test $(p<0.05)$.

\section{Results}

Perennial cyanobacterial blooms formed in the lake in different years were predominated by P. agardhii (Tab. 1). In the samples used in the presented study, cyanobacterial biomass accounted for about $99 \%$ of phytoplankton. The cyanobacterial biomass of the sample Pa-A consisted in $97 \%$ of $P$. agardhii and in about $3 \%$ of $A$. gracile and Dolichospermum spp. and the biomass of the sample Pa-B consisted in $95 \%$ of $P$. agardhii and in 5\% of M. aeruginosa. An analysis of oligopeptides (including MCs) contained in those cyanobacterial bloom samples revealed, however, that their composition differed considerably (Tab. 2). The crude extract Pa-A was obtained from the biomass of cyanobacteria (1142 $\mathrm{mg} \mathrm{FW} \mathrm{L}^{-1}$ ), which were more effective MC producers $\left(12.96 \mu \mathrm{g} \mathrm{MCs} \mathrm{mg}^{-1} \mathrm{FW}\right.$ ) than the cyanobacteria (sampled in another year), which contained only $0.20 \mu \mathrm{g} \mathrm{MCs} \mathrm{mg}^{-1} \mathrm{FW}$ (extract $\mathrm{Pa}-\mathrm{B}$ ) (Tab. 1). In the extract $\mathrm{Pa}-\mathrm{A}$, besides four $\mathrm{MC}$ variants, 10 oligopeptides belonging to two classes anabaenopeptins (5) and aeruginosins (5) - were present, while in the extract $\mathrm{Pa}-\mathrm{B}$, three MCs and 14 other oligopeptides belonging to three classes - anabaenopeptins (7), aeruginosins (6), and one planktocyclin (syn. cyanopeptolin) - were found (Tab. 2). The extracts contained three common variants of MCs (derivatives of MC-RR, $-\mathrm{LR}$, and 
B. Pawlik-Skowrońska et al.: Knowl. Manag. Aquat. Ecosyst. 2018, 419, 41

Table 1. Characteristics of two different Planktothrix-dominated bloom samples and their crude extracts.

\begin{tabular}{|c|c|c|c|c|c|c|c|c|}
\hline \multirow{2}{*}{$\begin{array}{l}\text { Species contribution } \\
\text { to the biomass }\end{array}$} & \multirow{2}{*}{$\begin{array}{l}\text { Extract } \\
\text { code }\end{array}$} & \multirow{2}{*}{$\begin{array}{l}\text { Biomass } \\
\left(\mathrm{mg} \mathrm{FW} \mathrm{L}^{-1}\right)\end{array}$} & \multirow{2}{*}{$\begin{array}{l}\text { Chlorophyll } \\
\text { a }\left(\mathrm{mg} \mathrm{L}^{-1}\right)\end{array}$} & \multirow{2}{*}{$\begin{array}{l}\text { Total } \\
\text { MCs } \\
\left(\mathrm{mg} \mathrm{L}^{-1}\right)\end{array}$} & \multirow{2}{*}{$\begin{array}{l}\text { MCs in } \\
\text { biomass } \\
\left(\mu \mathrm{g} \mathrm{mg}^{-1} \mathrm{FW}\right)\end{array}$} & \multicolumn{3}{|c|}{ MCs variants $(\%)$} \\
\hline & & & & & & $\begin{array}{l}\left.\mathrm{Asp}^{3}, \mathrm{Mdha}^{7}\right] \\
\mathrm{MC}-\mathrm{RR}+ \\
{\left[\mathrm{Ser}^{7}\right] \mathrm{MC}-\mathrm{RR}}\end{array}$ & $\begin{array}{l}{\left[\mathrm{Asp}^{3}, \mathrm{dha}^{7}\right]} \\
\text { MC-LR }\end{array}$ & $\begin{array}{l}{\left[\mathrm{Asp}^{3}\right]} \\
\mathrm{MC}-\mathrm{HtyR}\end{array}$ \\
\hline $\begin{array}{l}\text { P. agardhii }(97 \%), \\
\text { Aph. gracile }(1.8 \%) \text {, } \\
\text { Dolichospermum } \\
\text { spp. }(0.9 \%)\end{array}$ & $\mathrm{Pa}-\mathrm{A}$ & $1142 \pm 30$ & $29.66 \pm 0.07$ & $14.80 \pm 0.35$ & 12.96 & $95.0 \pm 0.4^{\mathrm{a}}$ & $3.2 \pm 1.7$ & $1.8 \pm 0.8$ \\
\hline $\begin{array}{l}\text { P. agardhii }(95 \%), \\
\text { M. aeruginosa }(5 \%)\end{array}$ & $\mathrm{Pa}-\mathrm{B}$ & $2776 \pm 69$ & $72.11 \pm 2.50$ & $0.55 \pm 0.01$ & 0.20 & $61.0 \pm 4.1$ & $38.6 \pm 4.0$ & $0.4 \pm 0.04$ \\
\hline
\end{tabular}

${ }^{\mathrm{a}}$ Only $\left[\mathrm{Ser}^{7}\right] \mathrm{MC}-\mathrm{RR}$ detected. Total MC concentration was set as $100 \%$. Data are expressed as means $\pm \mathrm{SD}, \mathrm{n}=5$.

Table 2. Characteristics of oligopeptides found in two different extracts of $P$. agardhii-dominated cyanobacterial biomasses.

\begin{tabular}{|c|c|c|c|c|}
\hline Oligopeptide's groups & Oligopeptides & $\mathrm{m} / \mathrm{z}[\mathrm{M}+\mathrm{H}]^{+}$ & Extract $\mathrm{Pa}-\mathrm{A}$ & Extract Pa-B \\
\hline \multirow[t]{4}{*}{ Microcystins } & {$\left[\mathrm{Asp}^{3}\right] \mathrm{MC}-\mathrm{HtyR}$} & 1045 & + & + \\
\hline & {$\left[\mathrm{Ser}^{7}\right] \mathrm{MC}-\mathrm{RR}$} & 1042 & + & \\
\hline & {$\left[\mathrm{Asp}^{3} \mathrm{Mdha}^{7}\right] \mathrm{MC}-\mathrm{RR}$} & 1024 & + & + \\
\hline & {$\left[\mathrm{Asp}^{3} \mathrm{dha}^{7}\right] \mathrm{MC}-\mathrm{LR}$} & 981 & + & + \\
\hline \multirow[t]{10}{*}{ Anabaenopeptins } & Anabaenopeptin A & 844 & + & + \\
\hline & Anabaenopeptin B & 838 & + & + \\
\hline & Anabaenopeptin $\mathrm{H}$ & 923 & & + \\
\hline & Anabaenopeptin G & 909 & & + \\
\hline & Anabaenopeptin HU892 & 893 & & + \\
\hline & Anabaenopeptin 915 & 916 & + & \\
\hline & Anabaenopeptin E/F & 851 & & + \\
\hline & Anabaenopeptin F & 851 & + & \\
\hline & Oscillamide Y & 858 & + & + \\
\hline & Cl-aeruginoside $126 \mathrm{~A}$ & & & \\
\hline \multirow[t]{7}{*}{ Aeruginosins } & Aeruginoside 716 & 749 & + & + \\
\hline & Aeruginoside 126A & 715 & + & + \\
\hline & Aeruginoside 126B & 691 & + & \\
\hline & Derivative of aeruginosin 89 & & & + \\
\hline & Aeruginosin 89 & 637 & + & + \\
\hline & Dechloro-aeruginosin 89 & 603 & + & + \\
\hline & $\mathrm{Cl}$-aeruginosin $126 \mathrm{~B}$ & 749 & & + \\
\hline Cyanopeptolins & Planktocyclin & 801 & & + \\
\hline
\end{tabular}

-HtyR) and seven common other oligopeptides. They differed in [Ser7]MC-RR, present only in the extract $\mathrm{Pa}-\mathrm{A}$ and the other 10 oligopeptides. For the first time, it has been documented that cyanobacterial extracts of a determined number and composition of oligopeptides (different from MCs) exerted toxic effects on the early stage of development of an aquatic plant. As shown in Figures 1 and 2, both the cyanobacterial extracts and pure MC-LR inhibited the growth of the first frond of young S. polyrhiza. After the four-day exposure, the surface area of the first frond (Fig. 1) in the control plants ranged from 14.7 to $27.1 \mathrm{~mm}^{2}$, while at the highest concentrations of the extracts it was smaller and ranged from 11.4 to $20.3 \mathrm{~mm}^{2}$ (Pa-A- exposed plants) and from 8.1 to $11.1 \mathrm{~mm}^{2}$ (Pa-B- exposed plants). Pure MC-LR at the lower concentration used (332 $\mu \mathrm{g} \mathrm{L}^{-1}$ ) inhibited the frond growth (Fig. 2a) to a similar extent (by approximately $30 \%-40 \%$ ) as the extract $\mathrm{Pa}-\mathrm{A}$ with an approximately four times higher concentration of MCs (containing also 10 other oligopeptides) and the extract $\mathrm{Pa}-\mathrm{B}$ with an approximately 10 times lower concentration of MCs (containing also 14 other oligopeptides) (Figs. 2b and 2c). A comparison of the two cyanobacterial extracts (Fig. 1) having different oligopeptide compositions indicated that the extract $\mathrm{Pa}-\mathrm{B}$ with a lower MC concentration, but obtained from a higher cyanobacterial biomass (Tab. 1) exerted a stronger inhibitory effect on the growth of the first frond of the plant than the extract $\mathrm{Pa}-\mathrm{A}$ with a considerably higher $\mathrm{MC}$ 


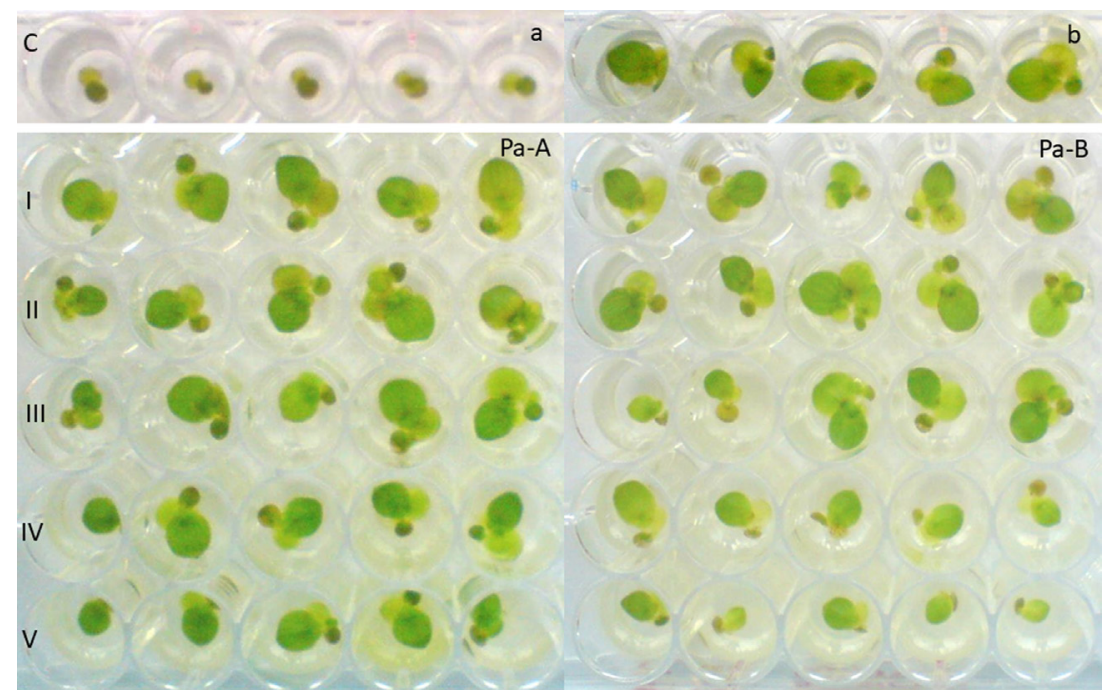

Fig. 1. Young S. polyrhiza response to cyanobacterial extracts of different oligopeptide composition. Controls free of extracts (C): 0 time (a), $96 \mathrm{~h}$ (b). Plants exposed for $96 \mathrm{~h}$ to extract Pa-A and extract Pa-B: I, II, III, IV, V indicate 16-, 8-, 4-, and 2-fold dilutions of the extracts, respectively, with increasing concentration of MCs (as indicated in Fig. $2 \mathrm{~b}$ and c).

concentrations but obtained from a smaller biomass of cyanobacteria.

As shown in Figures 3 and 4, both cyanobacterial extracts and pure MC-LR affected the plant fresh biomass and the root system of young $S$. polyrhiza in a dose-dependent manner. Interestingly, the highest toxicity was observed in plants exposed to the extract $\mathrm{Pa}-\mathrm{B}$ with lower MC concentrations but higher richness of the other oligopeptides (14). In plants exposed to pure MC-LR and the extract $\mathrm{Pa}-\mathrm{A}$ containing considerably higher $\mathrm{MC}$ concentrations but a lower richness of the other oligopeptides (10), the toxic effects were less pronounced. As shown in Figure 5, both cyanobacterial extracts and pure MC-LR exerted a lower toxic effect on the chlorophyll $a$ content in young plants than on the development of their fronds and roots. A comparison of the toxic effects (Tab. 3) caused by the cyanobacterial extracts with different MC concentrations and oligopeptide composition, albeit obtained from two equal cyanobacterial biomasses (indicated by chlorophyll $a$ ) suggests an essential contribution of the oligopeptides other than MCs to the toxicity observed in young Spirodela. The inhibition of root development (by $45 \%-48 \%$ ) was stronger than the decrease in the plant biomass $(32 \%$ $34 \%$ ), and both the effects did not correlate with the MC concentrations in the cyanobacterial extracts.

\section{Discussion}

Macrophyte communities play an essential role in the functioning of freshwaters; however, in eutrophic water bodies suffering from cyanobacterial blooms, their diversity and species richness is low. Only some species can survive under high phytoplankton biomass (Tarkowska-Kukuryk and Mieczan, 2017). The duckweed $S$. polyrhiza is a common species in the water bodies of the temperate climatic zone. The present study indicated that the test based on resting fronds, the turions of S. polyrhiza (Appenroth et al., 1996), is a useful method for the evaluation of the acute toxicity of bloom samples containing a variety of cyanobacterial metabolites. The results obtained in our study clearly show that the mixture of cyanobacterial metabolites found in $P$. agardhii-dominated bloom samples after the 4-day exposure had a toxic effect on different components of the young $S$. polyrhiza growth: stronger on the frond and root development than on the chlorophyll $a$ content in the plants. The observed inhibition of the young plants' development contributes to the better understanding of the impoverishment of macrophyte populations in cyanobacteria-dominated water bodies. As reported previously by Mathe et al. (2013), the crude extracts of cyanobacteria containing an undetermined mixture of metabolites caused negative alterations in aquatic plant cells. Because of the genetic variability of the individual taxa of cyanobacteria, a range of numerous secondary metabolites exhibiting various biological activities can be produced (Welker and von Döhren, 2006; Kurmayer et al., 2016). The populations of bloom-forming $P$. agardhii may consist of several chemotypes of different oligopeptide profiles composed of several variants of MCs, cyanopeptolins, anabaenopeptins, aeruginosins, and other metabolites (Rohrlack et al., 2008; Grabowska et al., 2014) as observed in our study as well. In eutrophic water bodies, usually, several species of cyanobacteria belonging to MC-producing genera Dolichospermum, Microcystis, and Planktothrix develop in mass in the same season (Pawlik-Skowrońska et al., 2013). All of them produce a wide range of oligopeptides, including different variants of anabaenopeptins, aeruginosins and their glycosylated forms (aeruginosides), and cyanopeptolins (Shin et al., 1997; Welker et al., 2004; Rouhiainen et al., 2010). As reported by Grabowska et al. (2014), in the same water body, $P$. agardhii populations differing considerably in terms of their peptide profiles can occur.

In the present study, the cyanobacterial extract with a higher richness of oligopeptides that caused a stronger inhibition of young $S$. polyrhiza was obtained from the biomass of $P$. agardhii $(95 \%)$ with $5 \%$ enrichment of Microcystis spp. It is probable that both species contributed to the production of the detected 

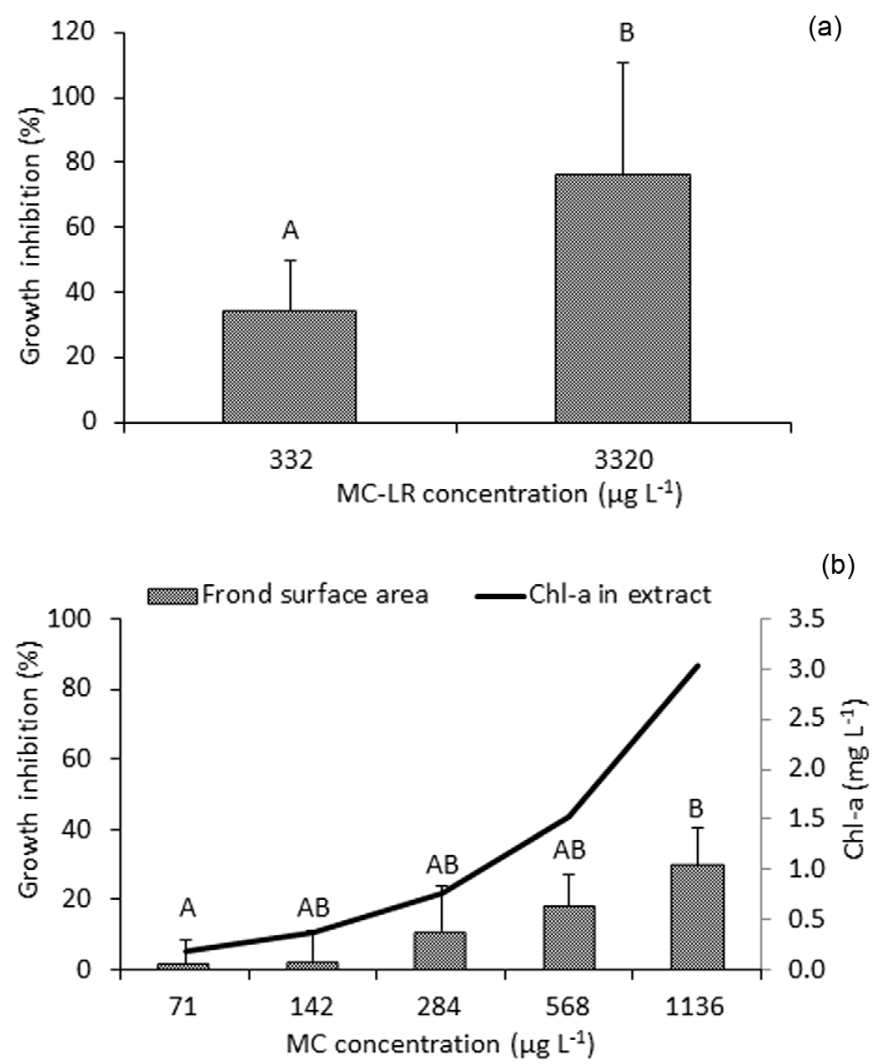

(c)

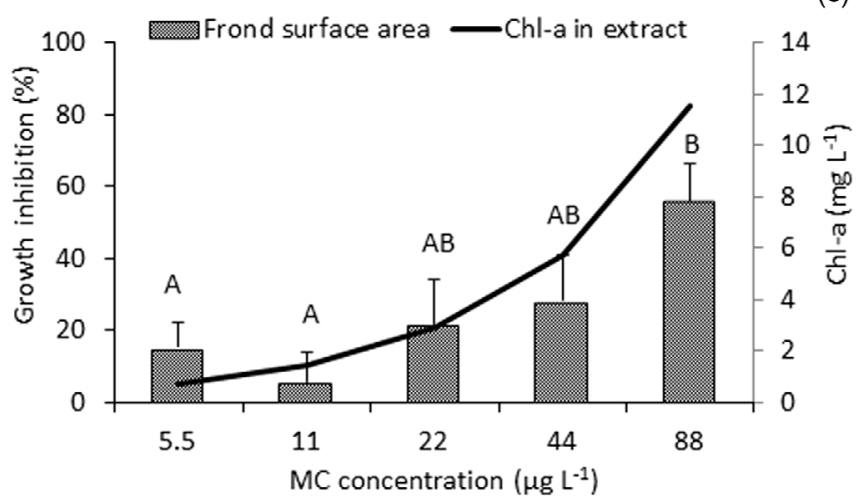

Fig. 2. Effect of pure MC-LR (a) and two cyanobacterial extracts of $P$. agardhii-dominated biomass $\mathrm{Pa}-\mathrm{A}(\mathrm{b})$ and $\mathrm{Pa}-\mathrm{B}$ (c) on the 96-h growth of the first frond of young $S$. polyrhiza. Growth in controls was set as $100 \%$. Data are expressed as means $\pm \mathrm{SE}, \mathrm{n}=5$. Different uppercase letters (A, B) indicate statistically significant differences between the growth of the first frond of S. polyrhiza exposed to different concentrations of MC-LR (a); different dilutions of the extracts Pa-A (b) and Pa-B (c) (ANOVA, Tukey's test, $p<0.05$ ).

oligopeptides. Our results strongly suggested that the mixture of the detected cyanobacterial oligopeptides, other than MCs (anabaenopeptins, aeruginosins, and cyanopeptolin), contributed to the toxicity towards the early stage of the $S$. polyrhiza development and in the case of the first frond growth and root number to a greater extent than the pure MC-LR did (at the highest concentration used). Among the sets of peptides found in the biomasses tested in the present study, there were numerous enzyme inhibitors (Czarnecki et al., 2006; Welker and von

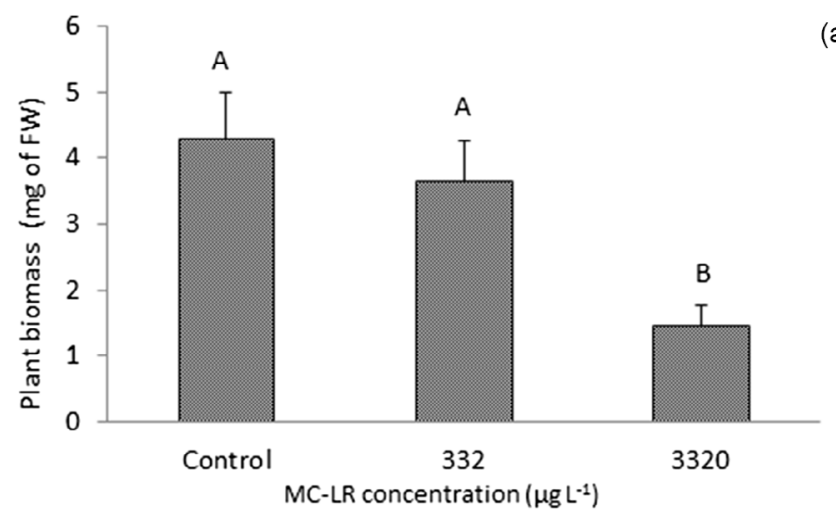

(a)
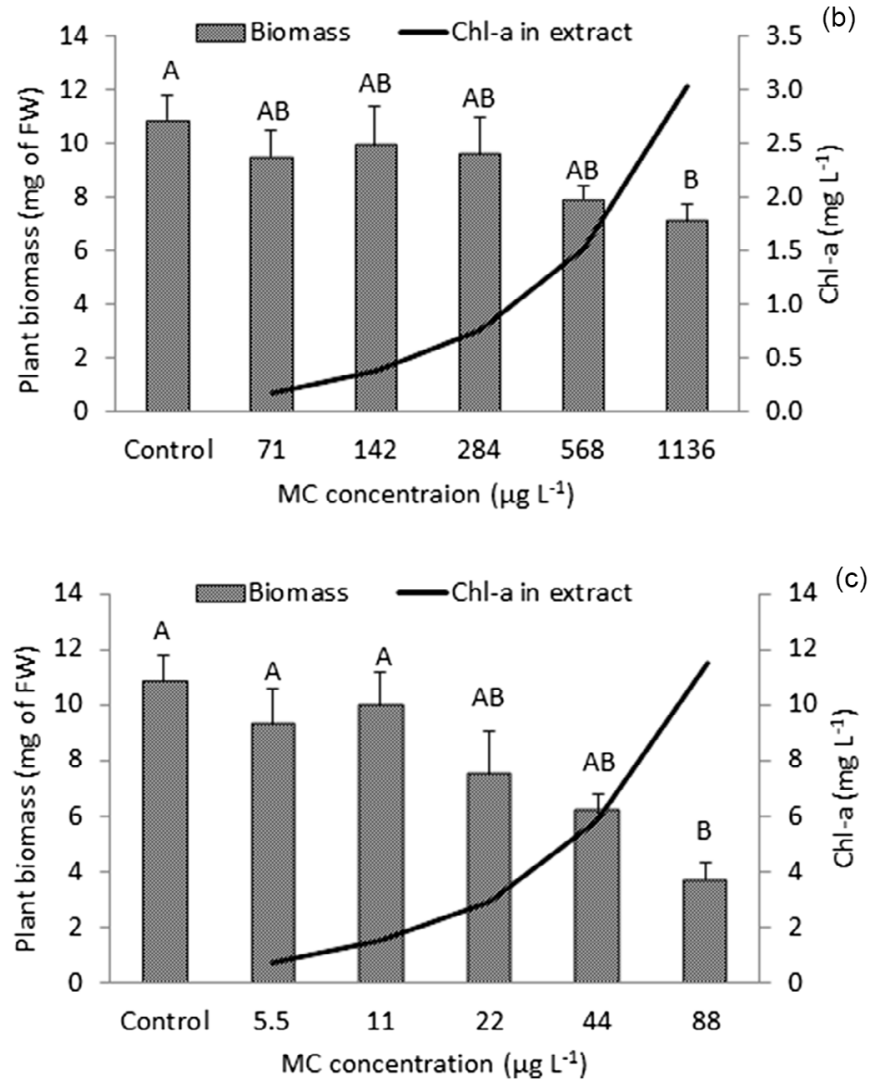

Fig. 3. Effect of pure MC-LR (a) and two cyanobacterial extracts PaA (b) and Pa-B (c) on the fresh biomass of S. polyrhiza. Data are expressed as means $\pm \mathrm{SE}, n=5$. Different uppercase letters (A, B) indicate statistically significant differences between fresh biomass of $S$. polyrhiza exposed to different concentrations of MC-LR (a); different dilutions of the extracts $\mathrm{Pa}-\mathrm{A}$ (b) and Pa-B (c) (ANOVA, Tukey's test, $p<0.05$ ).

Döhren, 2006; Mazur-Marzec et al., 2015). Their cytotoxicity and inhibitory activity against proteases and protein phosphatases in animal organisms as well as in vitro against carboxypeptidases have been reported (Namikoshi and Rinehart, 1996 and references therein; Gkelis et al., 2006; Harms et al., 2016). Thus far, no attention has been paid to the possible toxic effects of cyanobacterial oligopeptides other than MCs on aquatic plants, however, such effects have been reported for terrestrial plants (Mazur-Marzec et al., 2015). It seems quite 

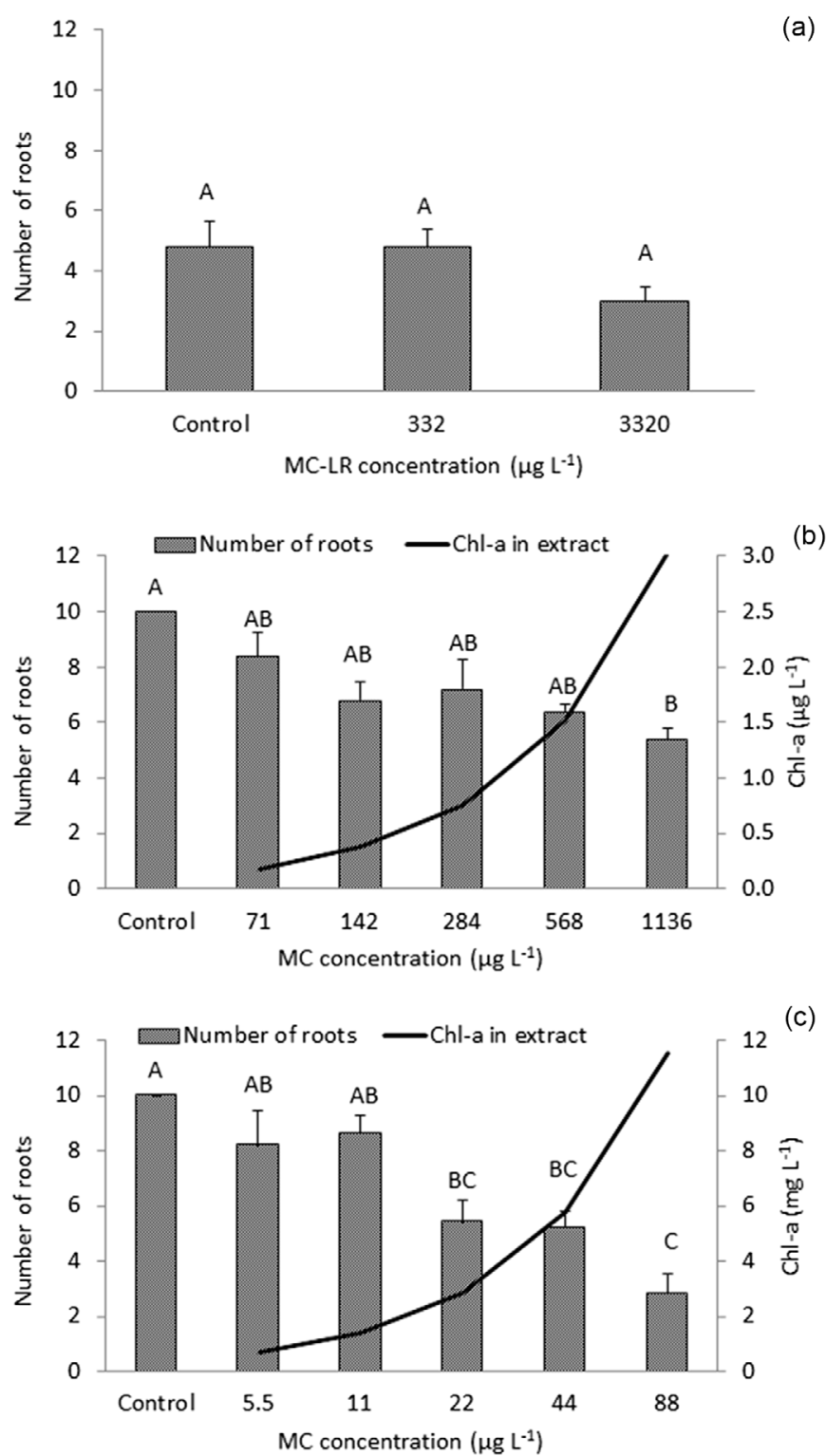

Fig. 4. Effect of pure MC-LR (a) and two cyanobacterial extracts PaA (b) and Pa-B (c) on development of root system of $S$. polyrhiza. Data are expressed as means $\pm \mathrm{SE}, n=5$. Different uppercase letters (A, B) indicate statistically significant differences between number of roots of $S$. polyrhiza exposed to different concentrations of MC-LR (a); different dilutions of the extracts Pa-A (b) and Pa-B (c) (ANOVA, Tukey's test, $p<0.05$ ).

possible that some anabaenopeptins-carboxypeptidase A inhibitors (Harms et al., 2016) may be involved in the inhibition of the MC metabolism and their step-wise degradation in aquatic plants. As suggested by Pflugmacher et al. (2001), the activity of carboxypeptidase is responsible for the Gly moiety cleavage from the cysteine-MCs conjugates, i.e., the intermediates in the $\mathrm{MC}$ metabolism in plants. Because of the lack of information on the accumulation and effects of cyanobacterial oligopeptides other than MCs on the aquatic plants, further studies are needed.
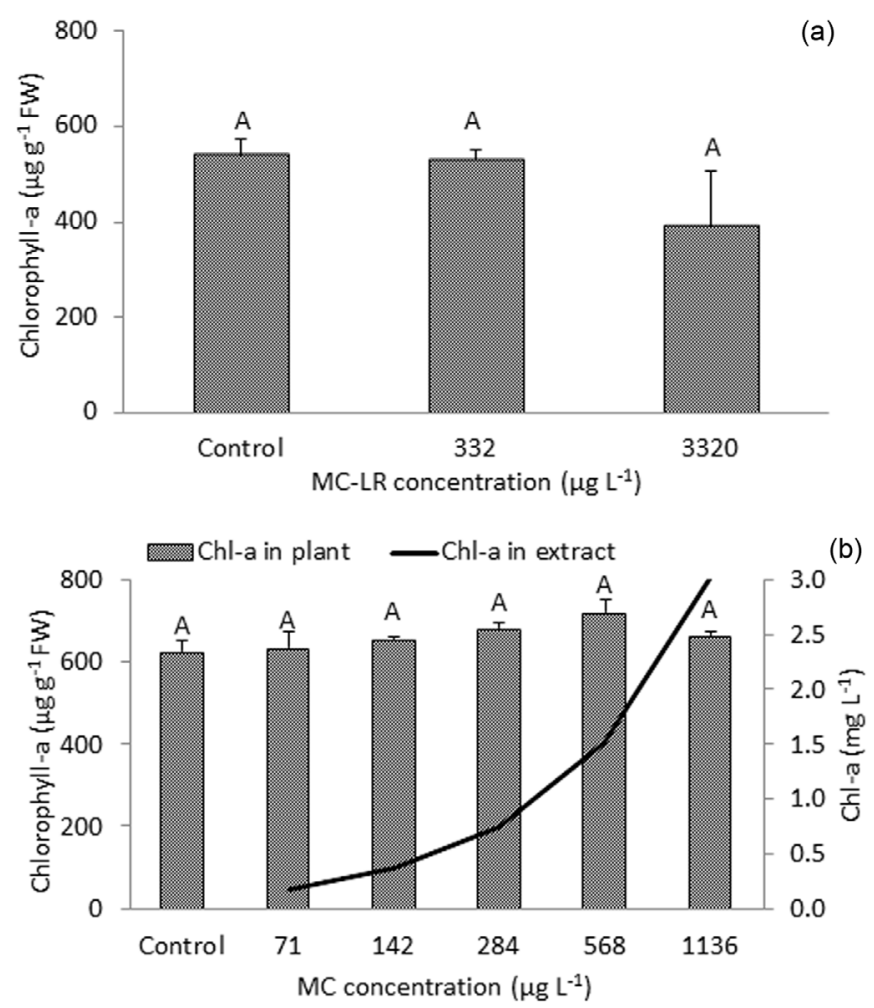

(b)

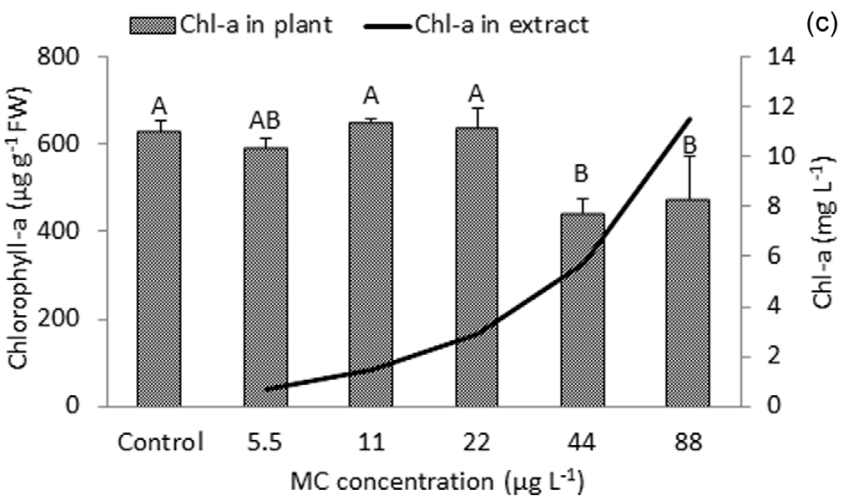

Fig. 5. Chlorophyll $a$ content in $S$. polyrhiza exposed for $96 \mathrm{~h}$ to pure MC-LR (a), cyanobacterial extracts Pa-A (b) and Pa-B (c). Data are expressed as means $\pm \mathrm{SE}, n=5$. Different uppercase letters (A, B) indicate statistically significant differences between chlorophyll $a$ content in S. polyrhiza exposed to different concentrations of MC-LR (a); different dilutions of the extracts Pa-A (b) and Pa-B (c) (ANOVA, Tukey's test, $p<0.05$ ).

\section{Conclusions}

The composition of secondary metabolites produced by the cyanobacterial populations accounts for the extent of toxic effects exerted on the main components of aquatic plant development. The variability of the mixtures of oligopeptides (other than MCs) produced by different species/chemotypes of cyanobacteria is an essential factor contributing to the cyanobacterial toxicity towards aquatic plants. The germinated 
Table 3. Comparison of toxic effects of different cyanobacterial extracts obtained from the equal cyanobacterial biomasses on $S$. polyrhiza, showing independence of MC concentration.

\begin{tabular}{llllll}
\hline Extract code & $\begin{array}{l}\text { Cyanobacterial } \\
\text { biomass }\left(\mathrm{Chl}-\mathrm{a} \mathrm{mg} \mathrm{L}{ }^{-1}\right)\end{array}$ & $\begin{array}{l}\mathrm{MCs} \text { total concentration } \\
\left(\mathrm{mg} \mathrm{L}^{-1}\right)\end{array}$ & $\begin{array}{l}\text { Number of oligopeptides } \\
(\mathrm{MCs}+\text { others })\end{array}$ & Growth inhibition (\%) \\
\hline $\mathrm{Pa}-\mathrm{A}$ & 3.0 & 1.136 & $14(4+10)$ & $34 \pm 8.1$ & $45 \pm 8.5$ \\
$\mathrm{~Pa}-\mathrm{B}$ & 3.0 & 0.021 & $17(3+14)$ & $32 \pm 7.6$ & $48 \pm 8.1$ \\
\hline
\end{tabular}

Data concerning growth inhibition are expressed as means \pm SE, $n=5$. Plant biomass and root number in controls were set as $100 \%$.

turions of $S$. polyrhiza can be used as a sensitive indicator of the cyanobacterial threat in aquatic ecosystems.

Conflicts of interest. The authors declare no conflicts of interest.

\section{References}

Appenroth K-J., Teller S, Horn M. 1996. Photophysiology of turion formation and germination in Spirodela polyrhiza. Biol Plantarum 38: 95-106.

Arnaud C, Quiblier C, Yepremian C, Got P, Groleau A, Vincon-Leite B, Bernard C, Troussellier M. 2008. Collapse of a Planktothrix agardhii perennial bloom and microcystin dynamicas in response to reduced phosphate concentrations in a temperate lake. FEMS Microbiol Ecol 65: 61-73.

Barrios CAZ, Nandini S, Sarma SSS. 2015. Effect of crude extract of Dolichospermum planctonicum on the demography of Plationus platulus (Rotifera) and Ceriodaphnia cornuta (Cladocera). Ecotoxicology 24: 85-93.

Briand E, Gugger M, Francois JC, Bernard C, Humbert JF, Quiblier C. 2008. Temporal variations in the dynamics of potentially microcystin-producing strains in a bloom-forming Planktothrix agardhii. Appl Environ Microbiol 74: 3839-3848.

Chlipala GE, Mo S, Orjala J. 2011. Chemodiversity in freshwater and terrestrial cyanobacteria - a source for drug discovery. Curr Drug Targets 12: 1654-1673.

Czarnecki O, Henning M, Lippert I, Welker M. 2006. Identification of peptide metabolites of Microcystis (Cyanobacteria) that inhibit trypsin-like activity in planktonic herbivorous Daphnia (Cladocera). Environ Microbiol 8: 77-87.

Gkelis S, Lanaras T, Sivonen K. 2006. The presence of microcystins and other cyanobacterial bioactive peptides in aquatic fauna collected from Greek freshwaters. Aquatic Toxicol 78: $32-41$.

Grabowska M, Kobos J, Toruńska-Sitarz A, Mazur-Marzec H. 2014. Non-ribosomal peptides produced by Planktothrix agardhii from Siemianówka Dam Reservoir SDR (northeast Poland). Arch Microbiol 196: 697-707.

Halvsted CB, Rohrlack T, Andersen T, Skulberg O, Edvardsen B. 2007. Seasonal dynamics and depth distribution of Planktothrix spp. in Lake Steinsfjorden (Norway) related to environmental factors. J Plankton Res 29: 471-482.

Harms H, Kurita KL, Pan L, Wahome PG, He H, Kinghorn AD, Carter GT, Linington RG. 2016. Discovery of anabaenopeptin 679 from freshwater algal bloom material: insights into the structure-activity relationship of anabaenopetin protease inhibitors. Bioorg Med Chem Lett 26: 4960-4965.
Hillebrand H, Dürselen CD, Kirschtel D, Pollingher U, Zohary T. 1999. Biovolume calculation for pelagic and benthic microalgae. $J$ Phycol 35: 403-424.

Jones GJ, Orr PT. 1994. Release and degradation of microcystin following algicide treatment of a Microcystis aeruginosa bloom in a recreational lake, as determined by HPLC and protein phosphatase inhibition assay. Water Res 28: 871-876.

Kurmayer R, Deng L, Entfellner E. 2016. Role of toxic and bioactive secondary metabolites in colonization and bloom formation by filamentous cyanobacteria Planktothrix. Harmful Algae 54: 69-86.

Mathe C, Hamvas MM, Vasas G. 2013. Microcystin-LR and cylindrospermopsin induced alterations in chromatin organization of plant cells. Mar Drugs 11: 3689-3717.

Mazur-Marzec H, Kaczkowska MJ, Błaszczyk A, Akcaalan R, Spoof L, Meriluoto J. 2013. Diversity of peptides produced by Nodularia spumigena from various geographical regions. Mar Drugs 11: 1-19.

Mazur-Marzec H, Błaszczyk A, Felczykowska A, Wohlfeld N, Kobos J, Toruńska-Sitarz A, Devi P, Montalvao S, D'souza L, Tammela P, Mikosik A, Bloch S, Nejman-Faleńczyk B, Węgrzyn G. 2015. Baltic cyanobacteria - a source of biologically active compounds. Eur J Phycol 50: 343-360.

Metcalf JS, Codd GA. 2012. Cyanotoxins. In: Whitton BA, ed. Ecology of Cyanobacteria II: Their Diversity in Space and Time. New York-London: Springer Science + Business Media B.V.

Mitrovic SM, Allis O, Furey A, James KJ. 2005. Bioaccumulation and harmful effects of microcystin-LR in the aquatic plants Lemna minor and Wolffia arrhiza and the filamentous alga Cladophora fracta. Ecotoxicol Envion Saf 61: 345-352.

Namikoshi M, Rinehart KL. 1996. Bioactive compounds produced by cyanobacteria. J Industr Microbiol 17: 373-384.

Nasri AB, Bouaïcha N, Fastner J. 2004. First report of a microcystin-containing bloom of the cyanobacteria Microcystis spp. in Lake Oubeira, Eastern Algeria. Arch Environ Con Tox 46: 197-202.

O'Neil JM, Davis TW, Burford MA, Gobler CJ. 2012. The rise of harmful cyanobacterial blooms: the potential roles in eutrophication and climate change. Harmful Algae 14: 313-334.

Pawlik-Skowrońska B, Pirszel J, Kornijów R. 2008. Spatial and temporal variation in microcystin concentrations during perennial bloom of Planktothrix agardhii in a hypertrophic lake. Ann LimnolInt J Lim 44 (2): 63-68.

Pawlik-Skowrońska B, Kalinowska R, Skowroński T. 2013. Cyanotoxin diversity and food web bioaccumulation in a reservoir with decreasing phosphorus concentrations and perennial cyanobacterial blooms. Harmful Algae 28: 118-125.

Pearl HW. 2014. Mitigating harmful cyanobacterial blooms in a human- and climatically-impacted world. Life 4: 988-1012.

Pflugmacher S. 2004. Promotion of oxidative stress in the aquatic macrophyte Ceratophyllum demersum during biotransformation of 
the cyanobacterial toxin microcystin-LR. Aquatic Toxicol 70: $169-178$.

Pflugmacher S, Wiegand C, Beattie KA, Krause E, Steinberg CEW, Codd GA. 2001. Uptake, effects and metabolism of cyanobacterial toxins in the emergent reed plant Phragmites australis (Cav.) Trin. Ex Steud. Environ Toxicol Chem 20: 846-852.

Pietsch C, Wiegand C, Ame MV, Nicklisch A, Wunderlin D, Pflugmacher S. 2001. The effects of cyanobacterial crude extracts on different aquatic organisms: evidence for cyanobacterial toxin modulatins factors. Enviorn Toxicol 16: 535-542.

PN-ISO 10260, 2002. Water quality. Measurement of biochemical parameters. Spectrophotometric determination of chlorophyll-a, PWN, Warszawa (in Polish).

Rohrlack T, Edvardsen B, Skulberg R, Halstvedt CB, Utkilen HC, Ptacnik R, Skulberg OM. 2008. Oligopeptide chemotypes of the toxic freshwater cyanobacterium Planktothrix can form subpopulations with dissimilar ecological traits. Limnol Oceanogr 53: 1279-1293.

Rohrlack T, Skulberg R, Skulberg OM. 2009. Distribution of oligopeptides of the cyanobacterium Planktothrix and their persistence in selected lakes in Fennoscandia. J Phycol 45: 1259-1265.

Romanowska-Duda Z, Mankiewicz J, Tarczyńska M, Walter Z, Zalewski M. 2002. The effects of toxic cyanobacteria (blue-green algae) on water plants and animal cells. Pol J Environ Sci 11: 561-565.

Rouhiainen L, Jokela J, Fewer DP, Urmann S, Sivonen K. 2010. Two alternative starter modules for the non-ribosomal biosynthesis of specific anabaenopeptin variants in Anabaena (Cyanobacteria). Chem Biol 17: 265-273.

Saqrane S, Ghazali IE, Ouahid Y, Hassni ME, Hadrami IE, Bouarab L, del Campo FF, Oudra B, Vasconcelos V. 2007. Phytotoxic effects of cyanobacteria extract on the aquatic plant Lemna gibba: microcystin accumulation, detoxification and oxidative stress induction. Aquatic Toxicol 83: 284-294.
Shin HJ, Murakami M, Matsuda H, Yamaguchi K. 1997. Aeruginosins 205-A and $-\mathrm{B}$, serine protease inhibitory glycopeptides from the cyanobacterium Oscillatoria aghardii (NIES-205). J Org Chem 62: 1810-1813.

Tarkowska-Kukuryk M, Mieczan T. 2017. Submerged macrophytes as bioindicators of environmental conditions in shallow lakes in eastern Poland. Ann Limnol - Int J Lim 53: $27-34$.

Toporowska M, Pawlik-Skowrońska B, Kalinowska R. 2014. Accumulation and effects of cyanobacterial microcystins and anatoxin-a on benthic larvae of Chironomus spp. (Diptera: Chironomidae). Eur J Entomol 111: 83-90.

Weiss J, Liebert HP, Brune W. 2000. Influence of microcystin-RR on growth and photosynthetic capacity of the duckweed Lemna minor L. J Appl Bot 74: 100-105.

Welker M, von Döhren H. 2006. Cyanobacterial peptides - nature's own combinatorial biosynthesis. FEMS Microbiol Rev 30: $530-563$.

Welker M, Christiansen G, von Döhren H. 2004. Diversity of coexisting Planktothrix (Cyanobacteria) chemotypes deduced by mass spectral analysis of microcystins and other oligopeptides. Arch Microbiol 182: 288-298.

Wiegand C, Pflugmacher S. 2005. Ecotoxicological effects of selected cyanobacterial secondary metabolites a short review. Toxicol Appl Pharm 203: 201-218.

Wiegand C, Peuthert A, Pflugmacher S, Carmeli S. 2002. Effects of microcin SF608 and microcystin-LR, two cyanobacterial compounds produced by Microcystis sp. on aquatic organisms. Environ Toxicol 17: 400-406.

Yepremian C, Gugger MF, Briand E, Catherine A, Berger C, Quiblier C, Bernard C. 2007. Microcystin ecotypes in a perennial Planktothrix aghardii bloom. Water Res 41: 4446-4456.

Cite this article as: Pawlik-Skowrońska B, Toporowska M, Mazur-Marzec H. 2018. Toxic oligopeptides in the cyanobacterium Planktothrix agardhii-dominated blooms and their effects on duckweed (Lemnaceae) development. Knowl. Manag. Aquat. Ecosyst., $419,41$. 